\title{
Managerial Overconfidence and Corporate Risk Management
}

\author{
Tim R. Adam*
}

Chitru S. Fernando** Evgenia Golubeva**

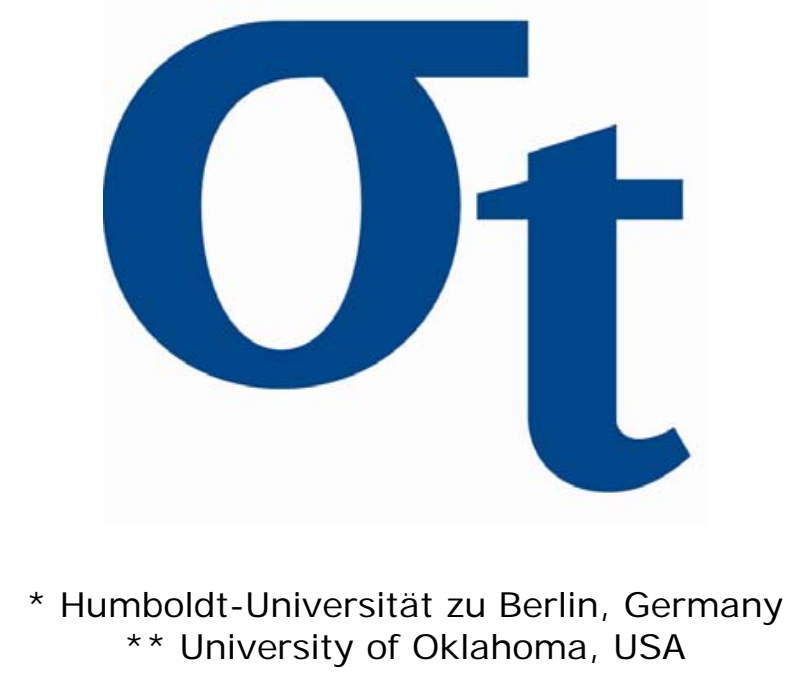

This research was supported by the Deutsche Forschungsgemeinschaft through the SFB 649 "Economic Risk".

http://sfb649. wiwi. hu-berlin. de ISSN 1860-5664 


\title{
Managerial Overconfidence and Corporate Risk Management*
}

\author{
Tim R. Adam \\ School of Business and Economics, Humboldt University of Berlin \\ Dorotheenstr. 1, 10099 Berlin, Germany \\ Tel.: +49 302093 5641; Fax: +49 3020935643 \\ E-mail:tim.adam@,hu-berlin.de \\ Chitru S. Fernando \\ Price College of Business, University of Oklahoma \\ 307 West Brooks, Norman, OK 73019, USA \\ Tel.: (405) 325-2906; Fax: (405) 325-7688 \\ E-mail:cfernando@ou.edu \\ Evgenia Golubeva \\ Price College of Business, University of Oklahoma \\ 307 West Brooks, Norman, OK 73019, USA \\ Tel: (405) 325-7727; Fax: (405) 325-7688 \\ E-mail:janya@ou.edu
}

\begin{abstract}
We show that managerial overconfidence, which has been found to influence a number of corporate financial decisions, also affects corporate risk management. We find that managers increase their speculative activities using derivatives following speculative gains, while they do not reduce their speculative activities following speculative losses. This asymmetric response follows from selective selfattribution: successes tend to be attributed to one's own skill, while failures tend to be attributed to bad luck. Thus, our results show that managerial behavioral biases can also impact corporate risk management.
\end{abstract}

November 20, 2011

JEL Classification: G11; G14; G32; G39

Keywords: corporate risk management; behavioral biases; managerial overconfidence; speculation

\footnotetext{
* We thank Alex Butler, Sudheer Chava, Louis Ederington, Gary Emery, Dirk Jenter, Swami Kalpathy, Leonid Kogan, Shimon Kogan, Nan Li, Gustavo Manso, Bill Megginson, Darius Miller, Jun Pan, Roberto Rigobon, Martin Ruckes, Antoinette Schoar, Oliver Spalt, Per Stromberg, Rex Thomson, Pradeep Yadav, and seminar participants at MIT, University of Oklahoma, Humboldt University, University of Texas at Dallas, Southern Methodist University, Texas Christian University, ESMT Berlin, 2008 FMA Europe meetings, 2008 FMA meetings, 2009 EFA meetings and 2010 AFA meetings for valuable discussions and comments. We are grateful to Ted Reeve for providing us with his derivatives surveys of gold mining firms and Leung Kam Ming for excellent research assistance. We also thank Anthony May and Jesus Salas for valuable assistance. This research has been supported by the CRC 649 of the German Science Foundation. A part of this research was conducted when Chitru Fernando was a visiting professor at the SMU Cox School of Business. He thanks SMU for their gracious hospitality and the National Science Foundation (Grant No. ECS-0323620) for financial support. We are responsible for any remaining errors.
} 


\title{
Managerial Biases and Corporate Risk Management
}

\begin{abstract}
We show that managerial overconfidence, which has been found to influence a number of corporate financial decisions, also affects corporate risk management. We find that managers increase their speculative activities using derivatives following speculative gains, while they do not reduce their speculative activities following speculative losses. This asymmetric response follows from selective self-attribution: successes tend to be attributed to one's own skill, while failures tend to be attributed to bad luck. Thus, our results show that managerial behavioral biases can also impact corporate risk management.
\end{abstract}

JEL Classification: G11; G14; G32; G39

Keywords: corporate risk management; behavioral biases; managerial overconfidence; speculation 


\section{Introduction}

The traditional theories of corporate risk management show that reducing risk can increase shareholder value by reducing expected taxes, bankruptcy costs, agency costs, information asymmetries, and payments to undiversified stakeholders of the firm. ${ }^{1}$ However, empirical tests of the predictions of these theories have met with only limited success. ${ }^{2}$ While each empirical study uncovers evidence that can be interpreted as being consistent with one or more of the theories of hedging, there is little consistency across studies. In addition, much of the variation in firms’ derivatives strategies, both cross-sectionally and over time, remains unexplained. This disparity between theory and practice is remarkably consistent with an argument advanced nearly 50 years ago by Working (1962), that the "traditional” risk avoidance notion of hedging matching one risk with an opposing risk - is deficient when it comes to explaining hedging behavior in practice. Indeed, the growing evidence that many managers systematically incorporate their market views into their risk management programs, ${ }^{3}$ but fail to generate positive cash flows from this "selective hedging” strategy on average, ${ }^{4}$ suggests that managers deviate at times from the pure rationality assumed by the neoclassical theories of hedging.

In this paper, we study the risk management activities of a sample of North American gold mining firms and present new evidence, which suggests that behavioral managerial biases affect corporate risk management strategies. A growing literature, both theoretical and empirical, studies the impact of managerial biases on corporate decisions. ${ }^{5}$ Several managerial biases,

\footnotetext{
${ }^{1}$ See, for example, Stultz (1984), Smith and Stultz (1985), Froot, Scharfstein and Stein (1993), DeMarzo and Duffie (1995), Leland (1998), Breeden and Viswanathan (1998) and Mello and Parsons (2000).

${ }^{2}$ See, for example, Tufano (1996), Mian (1996), Geczy, Minton and Schrand (1997), Graham and Smith (1999), Haushalter (2000) and Graham and Rogers (2002).

${ }^{3}$ See, for example, Dolde (1993), Stultz (1996), Bodnar, Hayt and Marston (1998), and Glaum (2002).

${ }^{4}$ See Adam and Fernando (2006) and Brown, Crabb and Haushalter (2006).

${ }^{5}$ Baker, Ruback, and Wurgler (2007) provide a comprehensive review of the literature on behavioral corporate finance.
} 
including loss aversion, mental accounting, and overconfidence, have been found to affect corporate investment policies, capital structure decisions, mergers and acquisitions, security offerings, and investment bank relationships. ${ }^{6}$ Given that the empirical evidence in favor of the neoclassical theories of hedging is weak, it seems warranted to examine whether behavioral managerial biases affect corporate risk management decisions.

In particular, we focus on the managerial overconfidence hypothesis (e.g., Heaton (2002); Malmendier and Tate (2005, 2008)), which implies that managers may be overconfident in their ability to beat the market, engaging in excessive position shifting under the mistaken belief that they have a relative information advantage. In particular, overconfidence is expected to increase following successes, but decrease less (if at all) following failures. This asymmetric response follows from selective self-attribution: successes tend to be attributed to one's own skill, while failures tend to be attributed to bad luck. Indeed, we find that managers tend to increase the level of their speculative activities using derivatives following speculative gains, but do not reduce their speculative activities following speculative losses. This asymmetric response, which persists after controlling for firm fixed-effects and several other time-varying firm characteristics, is difficult to reconcile with rational theories of risk management, but is consistent with the presence of managerial overconfidence.

The results are significant because they show that managerial behavioral biases can also impact corporate risk management. Recognizing that managers sometimes deviate from strict rationality is likely to improve our understanding of corporate risk management decisions and help close the gap between the observed practice of risk management and the extant neoclassical theories that seek to explain it.

\footnotetext{
${ }^{6}$ Studies include Roll (1986), Loughran and Ritter (2002), Heaton (2002), Ljungqvist and Wilhelm (2005), Malmendier and Tate (2005, 2008), Ben-David, Graham and Harvey (2007), Billett and Qian (2008), Goel and Thakor (2008), Sautner and Weber (2009), and Gervais, Heaton and Odean (2009).
} 
The remainder of the paper is organized as follows. Section 2 discusses the relevant literature and derives testable hypotheses. Section 3 describes our sample, the construction of our variables and the empirical methodology. Section 4 presents the empirical evidence on how speculation responds to speculative gains and losses. Section 5 summarizes the results and presents our conclusions.

\section{Empirical Hypotheses}

The objective of this paper is to test whether managerial behavioral biases are likely to affect corporate risk management decisions. As documented by Baker, Ruback, and Wurgler (2007) in their excellent review of the growing literature on behavioral corporate finance, several managerial behavioral biases have been shown to affect corporate decisions. We investigate the potential effects of managerial overconfidence on corporate risk management decisions.

Managerial overconfidence has been widely documented in the recent literature (see, for example, Russo and Schoemaker (1992), Griffin and Tversky (1992) and Heaton (2002)). Overconfident managers systematically overestimate the probability of good outcomes (and correspondingly, underestimate the probability of bad outcomes) resulting from their actions (Heaton (2002)). In a dynamic setting, overconfidence coupled with biased self-attribution (Miller and Ross (1975)), where managers credit themselves for successes while blaming outside factors for failures, cause managerial overconfidence to increase following successes but not commensurately decrease following failures (Daniel, Hirshleifer and Subrahmanyam (1998); Gervais and Odean (2001)). The implications for corporate financial decisions are that overconfident managers act more decisively and aggressively, and that this behavior intensifies following successes. Several studies, including Malmendier and Tate (2005, 2008), Ben-David, Graham and Harvey (2007), Billett and Qian (2008), and Malmendier, Tate and Yan (2011), 
report empirical evidence consistent with overconfident managers, while Barber and Odean (2000) report similar evidence in the context of overconfident individual investors.

We test the overconfidence hypothesis in the context of corporate risk management. There is ample evidence that managers incorporate their market views into their hedging decisions, and thus hedge "selectively."7 Adam and Fernando (2006) and Brown, Crabb and Haushalter (2006) document significant time-series variation in the size of the hedge positions of gold mining firms, which may reflect managers' changing market views about future gold prices. In the absence of an information advantage with respect to gold prices, however, incorporating a manager's private market view into a hedging program is inconsistent with neoclassical theories of risk management. Indeed, Adam and Fernando (2006) and Brown, Crabb and Haushalter (2006) do not find systematic gains from selective hedging, which implies that managers of gold mining firms do not possess an information advantage on average. Thus, the significant timeseries variation in firms' hedge positions is likely to be inconsistent with rational explanations of corporate hedging.

The managerial overconfidence hypothesis applied in the context of corporate speculation implies that managers grow more overconfident following past speculative successes, leading to a more aggressive pursuit of speculative strategies, while past failures would diminish managers’ willingness to speculate to a lesser degree, if at all. Hence, we expect an asymmetric relation between speculative activities and the past performance of speculative positions, where managers increase their speculative activities following successes in speculation, while they do not commensurately decrease speculation following failures in speculation.

\footnotetext{
${ }^{7}$ See Dolde (1993), Stultz (1996), Bodnar, Hayt and Marston (1998), and Glaum (2002).
} 


\section{Data and Methodology}

Our sample consists of 92 gold mining firms in North America, which are included in the Gold and Silver Hedge Outlook, a quarterly survey of derivatives activities conducted by Ted Reeve, an analyst at Scotia McLeod, from 1989 through 1999, when he discontinued the survey. ${ }^{8}$ These 92 firms represent the majority of firms in the gold mining industry (see Tufano (1996) and Adam and Fernando (2006)). Firms not included in the survey tend to be small or privately held corporations.

The survey contains information on all outstanding gold derivatives positions, their size and direction, maturities, and the respective delivery prices for each instrument (forwards, spotdeferred contracts, gold loans and options). This derivatives data is described in detail in Adam (2002). We hand-collect operational data: gold production (in ounces), production costs per ounce of gold, and gold reserves, from firms' annual reports. The data on firm characteristics such as size, market-to-book, leverage, liquidity, existence of a credit rating, and payment of quarterly dividends comes from Compustat. Data on managerial compensation is from ExecuComp, supplemented by hand collection from proxy statements where necessary. All variable notations and definitions are provided in Appendix 1.

We measure the extent of derivatives usage at a given point in time $t$ with time to maturity $i$ by a hedge ratio $H R(i)_{t}$, defined as follows:

$$
H R(i)_{t}=\frac{N(i)_{t}}{E_{t}\left[\operatorname{Prod}_{t+i}\right]},
$$

where $N(i)_{t}$ is the sum of the firm's derivatives positions in place at time $t$ (in ounces of gold) that mature in $i$ years, weighted by their respective deltas, as in Tufano (1996). $E_{t}\left[\operatorname{Prod}_{t+i}\right]$ is the

\footnotetext{
${ }^{8}$ While some post-2000 hedging data is available from accounting disclosures and other sources, this data lacks the level of detail and consistency across firms that has made the Scotia McLeod survey data invaluable for many empirical studies of corporate hedging, including Tufano (1996, 1998), Fehle and Tsyplakov (2005), Adam and Fernando (2006), and Brown, Crabb and Haushalter (2006).
} 
firms's expectation of its gold production (in ounces of gold) at time $t+i$ as of time $t$. The maturity $i$ of a derivatives position can be 1, 2, 3, 4, or 5 years, although most derivatives activity takes place with contracts that mature within three years. To check robustness of our results we aggregate (a) contracts with 1-3 years maturity and (b) contracts with 1-5 years maturity.

The derivatives survey reports the expected production for each hedge horizon $i$ whenever a firm has derivatives positions outstanding that mature in $i$ years. If a firm does not hedge a particular maturity, then the expected production figures are missing. In this case we use the actual gold production in year $t+i$. Since most firms do not hedge their gold production beyond three years, the problem of missing expected production figures increases with the hedge horizon. Therefore, we also define an alternate hedge ratio, $H R_{\text {Res }}(i)_{t}$, that does not rely on expected production but scales a firm's total derivatives position by its total gold reserve (see Jin and Jorion (2006)):

$$
H R_{\text {Res }}(i)_{t}=\frac{N(i)_{t}}{\text { Gold Reserve }_{t}} .
$$

In addition to helping overcome potential issues associated with missing production data, scaling by reserves is also a useful robustness check of our analysis using production-based hedge ratios, due to the possibility that some time-series variation in the production-based hedge ratio may be due to unplanned variations in expected production rather than a change in the firm's derivatives positions.

We observe the above hedge ratios every quarter from December 1989 to December 1999. This data allows us to measure the extent of speculation (selective hedging) by the timeseries volatility in hedge ratios. To obtain quarterly volatility estimates while also maximizing the number of observations in our relatively small sample, we follow the existing literature on volatility estimation and calculate volatility by the absolute change in a firm's hedge ratio. 
Alizadeh, Brandt, and Diebold (2002) review the large body of literature that estimates timevarying volatility using two daily observations: either open and close, or high and low. They argue, in particular, that the range, or the difference in log prices between daily high and daily low, is a good proxy for daily volatility. To quote, “...the discretized stochastic volatility model is difficult to estimate because the sample path of the asset price within each interval is not fully observed.... In practice, we are forced to use discretely observed statistics of the sample paths, such as the absolute or squared returns over each interval, to draw inferences about the discretized log volatilities and their dynamics...” The measure advocated by Alizadeh et al. (2002) has been used not only in market microstructure but also, for example, in asset pricing research. Ang, Hodrick, Xing, and Zhang (2006) mention using the range-based volatility measure as a proxy for innovations in aggregate market volatility, in order to estimate whether exposure to these innovations is a priced risk. Thus, we define the extent of speculation in quarter $t, V_{t}$, as the absolute value of the difference in the natural logarithms of the hedge ratios at the beginning and the end of each quarter. ${ }^{9}$

$$
V_{t}=A B S\left[L N\left(H R_{t} / H R_{t-1}\right)\right]
$$

This approach permits us to obtain quarterly volatility estimates, in contrast to (at best) annual volatility estimates that we would obtain using the time-series standard deviation of hedge ratios. $^{10}$

\footnotetext{
${ }^{9}$ For the purpose of measuring percentage changes, whenever a firm reports a zero hedge (unless it reports a zero value in both the beginning and the end of the quarter), we substitute a very small value. The percentage change is then calculated as the difference of the natural logarithms from quarter (t-1) to quarter $t$.

${ }^{10}$ An apparent refinement would be to estimate predicted hedge ratios as in Adam and Fernando (2006) and use the hedge ratio residuals to compute speculation. However, as demonstrated by Adam and Fernando (2006) in their robustness checks, speculation computed using hedge ratio residuals does not yield substantively different results to speculation computed using total hedge ratios, which may be due in part to the inability of fundamental variables to explain the variation in hedge ratios.
} 
We use several constructs to measure the past performance of firms' derivatives activities. First, we compute the quarterly total cash flows generated from derivatives positions per ounce of gold hedged, as in Adam and Fernando (2006). Second, we recalculate the quarterly cash flows assuming a firm had maintained a constant hedge ratio ("benchmark cash flows”). The difference between the total derivatives cash flow and the cash flow computed using this fixed hedge ratio benchmark is the cash flow that we attribute to selective hedging. ${ }^{11}$ Positive selective hedging cash flows constitute "speculative gains" and negative selective hedging cash flows constitute "speculative losses." Selective hedging cash flow is an attractive measure because it reflects the part of the cash flow that results directly from managerial market timing, i.e., speculative, actions. ${ }^{12}$ Finally, in addition to the above cash flow measures, we also calculate the quarterly derivatives book profit (or loss), which is computed as the quarterly change in the value of derivatives positions in dollars per ounce hedged. Please refer to Appendix 2 for the calculation of quarterly changes in the book value of derivatives positions.

Tables 1 and 2 show the descriptive statistics and the correlations for the different hedge ratios and hedge ratio volatility measures.

\section{[Place Tables 1 \& 2 about here]}

Several observations emerge from these tables. Consistent with Adam and Fernando (2006), selective hedging cash flows average at around zero, suggesting that selective hedging does not add value to the firm on a systematic basis. We notice that the hedge ratios of different maturities are all significantly correlated with one another. However, the correlations are weaker between shorter-maturity and longer-maturity hedge ratios. The aggregate hedge ratios are less

\footnotetext{
${ }^{11}$ Adam and Fernando (2006) provide details on the computation of these cash flows.

${ }^{12}$ For example, suppose a manager believes that the gold price is going to rise and therefore reduces the hedge ratio relative to the benchmark. If she is correct in her forecast, then the total derivatives cash flow will be negative (since she is short overall) but the selective component will be positive: the firm does not lose as much on the hedge as it could have.
} 
than perfectly correlated with one another, substantiating the need to check robustness of our results with respect to different hedge ratio definitions. The same general conclusions hold for the hedge ratio volatilities.

\subsection{Basic methodology}

Our basic methodology is to run panel regressions with firm fixed effects in order to focus on the time-series variation in hedge ratios and hedge ratio volatility. Our test of managerial overconfidence, which is based on the relationship between hedge ratio volatility and past speculative gains and losses, needs to be restricted to active hedgers only (i.e., firms that have non-zero hedge ratios and report non-zero cash flows in the previous period). This requirement is due to the fact that the overconfidence hypothesis conditions managerial activity on the results of previous activity. In addition, leaving non-hedging firm-quarters in the sample may lead to a spurious regression result with zero past cash flows from derivatives positions "explaining” zero hedge ratio volatility next period. Hence, we estimate the panel regression with firm fixed effects on a reduced sample of active hedgers.

For robustness we repeat our tests using the two-step Heckman (1979) procedure with selection. In the first stage, we model the existence of hedging activity as a function of variables that are predicted by extant hedging theory to be determinants of hedging -- firm size, market-tobook ratio, liquidity, leverage, dividend payment, credit rating, and the likelihood of financial distress (Tufano (1996), Haushalter (2000)). We say that a firm has hedging activity if two conditions hold: (1) the beginning or the end-of-quarter hedge ratio is non-zero; and (2) cash flows from derivatives positions in the previous quarter are non-zero. In the second stage of the Heckman two-step procedure, we test whether the hedge ratio volatility is driven by past success 
of the derivatives positions for the firms that exhibit hedging activity as described above. Further methodological details are provided in Section 4.

Our unique data permits us to employ a methodology that is distinct from and complements the techniques employed in the other studies of corporate managerial biases. Existing studies fall under two categories: surveys, as in Ben-David, Graham, and Harvey (2007); and cross-sectional studies, as in Malmendier and Tate (2005). These studies examine a variety of characteristics that are likely to affect the degree to which managers exhibit behavioral biases. Examples include personal and professional characteristics (age, tenure, education, etc.) and personal wealth management practices (the tendency to hold disproportionate amounts of one's own firm's stock, and the failure to exercise vested options). The question in these studies is whether cross-sectional differences across managers explain actions that are attributable to behavioral biases. Our work complements the prior studies by focusing on time-series patterns that may characterize behavioral biases, examining how managers as a group respond to market movements and their own past performance. As noted before, this complementary perspective is made possible by our unique data set, which contains quarterly observations on all outstanding gold derivatives positions of a sample of 92 North American gold mining firms from 1989-1999. The key advantage of this data set is that we are able to infer actual derivatives transactions and the corresponding cash flows as well as observe the estimates of expected production, which is a unique feature of our data set.

\subsection{Controlling for alternative explanations}

An alternative explanation for an increase in speculation following high derivatives cash flows derived from speculation is that managers simply have more cash to use at their discretion 
or that positive cash flows from speculation improve the firm's financial strength. We control for a firm's liquidity and financial strength to account for this possibility by including a dividend dummy, rating dummy, quick ratio, leverage and Altman's (1968) Z-score as control variables. ${ }^{13}$

Another possibility is that although selective hedging does not benefit shareholders, it may benefit managers due to incentive compensation (Stulz (1996)). While the potential link between selective hedging and managerial compensation is explored in several recent studies, the results are mixed, with only weak evidence that managerial compensation significantly affects selective hedging and no consensus on the direction of the relationship. ${ }^{14}$ Nevertheless, we control for managerial compensation variables to allow for this possibility in our hedging sample.

Finally, as pointed out by Campbell and Kracaw (1999), financially constrained firms with good projects may speculate more to generate more funds for optimal investment. Investment opportunities may also affect the degree to which firms choose to hedge due to the need to raise external financing (Froot, Scharfstein and Stein (1993)). We account for both financial constraints and growth opportunities by including standard control variables such as debt-to-equity and market-to-book ratios.

\section{Empirical Evidence: Managerial Responses to Speculative Gains and Losses}

In this section, we test the managerial overconfidence hypothesis by examining the relation between speculation (measured by hedge ratio volatility) and past speculative gains and losses.

\footnotetext{
${ }^{13}$ It is important to note, however, that in contrast to positive speculative cash flows from derivatives, positive total derivatives cash flow need not make the overall financial position of the firm stronger because positive hedge cash flows on derivatives positions would typically offset losses due to gold price declines.

${ }^{14}$ Géczy, Minton and Schrand (2007) find that CEO stock price sensitivity is negatively related to speculation while CFO stock price sensitivity is positively related. Beber and Fabbri (2006) find no consistent relation between CEO delta and selective hedging. Brown, Crabb and Haushalter (2006) find no systematic relationship between selective hedging and several ownership and compensation measures.
} 
The overconfidence hypothesis maintains that, all else equal, if past speculative activity was successful, resulting in cash flow gains, then the manager will increase his/her speculative activities in the next period. If, however, past speculative activity was unsuccessful, resulting in cash flow losses, then there would be no commensurate reduction in speculative activities. In other words, we expect an asymmetric relation between the degree of speculative activity and past speculative cash flows.

\subsection{Initial panel regressions without asymmetry effects}

We begin by examining the general relationship between derivatives cash flows and subsequent speculative activity. Tables 3 and 4 show the results of the firm fixed effects panel regressions of the hedge ratio volatility on past cash flows and book profits from derivatives positions per ounce of gold hedged. We present the results for the volatility of the one-year hedge ratio, the three-year aggregate hedge ratio scaled by expected production, the three-year aggregate hedge ratio scaled by reserves, and the five-year hedge ratio scaled by reserves. Table 3 reports the results for a specification that employs total derivatives cash flows along with derivatives book profit as independent variables. Our interest in this specification is to investigate whether speculative activity responds to past derivatives cash flows and/or book profits. Table 4 reports

the corresponding results using selective hedging cash flows (i.e., the speculative component of total derivatives cash flows), which is our primary variable of interest.

[Place Tables 3 and 4 about here]

Since we are interested in testing the hypothesis that successful past speculative derivatives activity will lead to higher speculation in the future, we perform these regressions after eliminating firm quarters where the firm had zero cash flows from derivatives positions, 
and also eliminating observations where both beginning-of-quarter and end-of-quarter hedge ratios were zero. In all of the models, we include seasonal dummy variables as controls; however, doing so is mostly a concern with the one-year hedge ratio, which exhibits some seasonal variation, whereas the aggregate hedge ratios exhibit virtually no seasonal variation. As discussed in Section 3.3, we also control for firm characteristics that may affect a firm's level of speculative activity, such as liquidity, financial strength, and growth opportunities.

As evident from Table 3, we observe a positive relationship between hedge ratio volatility and previous quarter total derivatives cash flows, which is robust to model specification in terms of both magnitude and statistical significance. However, we do not observe any relationship with the book profit. This result indicates that speculation responds to derivatives cash flows but not to book profits. We then refine the specification to employ the selective hedging component of derivatives cash flows. From Table 4, we observe that the relationship between hedge ratio volatility and selective hedging cash flows is positive and significant, providing evidence in favor of the hypothesis that the success of past selective hedging leads to higher levels of speculation in the future. Again, we do not find a significant relationship with book profits. Nonetheless, speculation is also positively related to benchmark cash flows, which is consistent with our observation in Table 3 for total derivatives cash flows.

Given that the tests reported in Tables 3 and 4 were performed on a reduced sample, we next perform robustness checks to control for the possibility of selection bias by allowing for the two sequential decisions of the firm, (1) whether or not to be a derivatives user and (2) conditional on being a derivatives user, how much to speculate. We estimate the two-step Heckman procedure with selection. In the first stage, we estimate a PROBIT model, where the dependent variable is equal to zero if (1) either the firm has zero hedge ratios in both the 
beginning and the end of quarter t; or (2) the firm had zero cash flows from hedging operations in quarter $\mathrm{t}-1 .{ }^{15}$ We estimate the likelihood of derivatives usage as a function of several firm characteristics: size, market-to-book ratio, the ratio of book debt to book equity, quick ratio, dividend-payer status, existence of a credit rating, and Altman's Z-score. In the second stage, we estimate the relationship between hedge ratio volatility and past cash flows and book profits from derivatives positions conditional on the firm being a derivatives user. The results from the two stages of the Heckman procedure are presented in Tables 5 and 6, respectively.

[Place Tables 5 and 6 about here]

From Table 5, we observe that firms that use derivatives are large firms with low growth opportunities (as indicated by low market-to-book ratios), conservative leverage policies, and higher financial constraints/low liquidity. These results are consistent with previously reported findings by Geczy, Minton and Schrand (1997), Bodnar, Hayt and Marston (1998) and Haushalter (2000).

The Heckman second-stage results reported in Table 6 are consistent with our previous findings reported in Tables 3 and 4. In all regression specifications, we observe a positive and significant relationship between hedge ratio volatility and past cash flows from derivatives positions, whether total derivatives cash flows or selective hedging cash flows and benchmark cash flows. We observe no relationship between hedge ratio volatility and past book profits from derivatives positions.

We next perform one more robustness check to control for managerial compensation as discussed in Section 3.3. Tables 7 and 8 present the results of the regressions of hedge ratio volatility on past cash flows while controlling for the managerial compensation variables (delta

\footnotetext{
${ }^{15}$ We also run the first stage estimation using only the first condition (non-zero hedge ratios) to define hedging activity and obtain similar results. They are not reported due to space constraints but are available on request.
} 
and vega) of the CEO and the CFO. The regressions are univariate due to the limited number of managerial compensation observations in our sample. However, the regressions indicate that overall, our inference regarding the effect of derivatives cash flows on speculation remains unaffected while the managerial compensation variables are statistically insignificant.

[Place Tables 7 and 8 about here]

\subsection{Accounting for asymmetry effects}

Having established the relation between speculation and derivatives cash flows, we now turn to our test for the presence of managerial overconfidence in our sample firms. We do so by examining the asymmetry in the relationship between derivatives cash flows and speculation. For this purpose, we run the following regression with dummy variables:

$$
V_{t}=a+b_{1} S C F_{t-1} \cdot I_{1}+b_{2} S C F_{t-1} \cdot I_{2}+\text { CONTROLS }_{t}+\varepsilon_{t}
$$

In this regression, $I_{1}\left(I_{2}\right)$ is a dummy variable that equals one if the selective hedging cash flow during the last quarter was positive (negative) and zero otherwise. We choose selective hedging cash flow to be the dependent variable because selective hedging cash flow is the direct consequence of speculative decisions made by the manager in the past, and therefore is more directly related to the extent to which past speculation was successful than total cash flows. We include the benchmark cash flow, along with the firm characteristics, in the matrix of control variables. $^{16}$

We estimate this regression first on a reduced sample of firm-quarters for active hedgers and next, using the Heckman two-step procedure for robustness. The results of the second-stage

\footnotetext{
${ }^{16}$ Nevertheless, we check robustness of the results to using total derivatives cash flow and find that the general result is similar in spirit although less significant. The results are not reported but are available upon request.
} 
Heckman procedure with controls are presented in Table $9 .{ }^{17}$ While the asymmetric response of hedge ratio volatility to selective cash flow persists in this alternative specification, the significance of the benchmark cash flow variable is diminished.

[Place Table 9 about here]

From both Table 8 and Table 9, we observe that the relationship between hedge ratio volatility and past selective hedging cash flows is strongly positive only if the past selective hedging cash flows are positive. A one-standard deviation increase in selective hedging cash flow leads to a 0.2774 increase in the quarterly volatility of the one-year hedge ratio, which is $22.5 \%$ of the sample mean of 1.2325 . When selective hedging cash flows are negative, however, we observe no significant relationship except in the case of one-year hedge ratio volatility. However, while we would still expect a positive coefficient for one-year hedge ratio volatility with negative selective hedging cash flows if the relation between speculation and selective hedging cash flow is symmetric (since speculation should decrease as speculation losses increase) this is the opposite of what we observe for one-year hedge ratio volatility. Thus, our evidence here strongly supports an asymmetric relation between speculative activity and selective hedging cash flows, which confirms the managerial overconfidence hypothesis for our sample firms. Managers increase speculative activity following successes (as their overconfidence rises) but do not symmetrically reduce it following failures. This result is robust to the inclusion of firm characteristics that may affect the fundamental hedging needs of the firm, as well as to controlling for possible selection biases.

\footnotetext{
17 The results of the panel regressions on the reduced sample are qualitatively similar to the Heckman regressions and are available on request.
} 


\subsection{Other robustness checks}

In addition to controlling for the rational explanations as laid out in Section 3.3, we also perform a few more robustness checks. First, past cash flows as well as derivatives book profits may be related to movements in the price of gold over the same quarter. This concern is mitigated by the fact that derivatives cash flows are the result of hedging decisions taken in the distant past as well as more current decisions and therefore, the recent change in the price of gold may not have a strong effect. Additionally, this issue is much less of a concern for selective hedging cash flows, which is our main variable of interest. Nevertheless, in unreported tests we include the change in the price of gold in our regressions without a substantive effect on our results. In the two-stage Heckman framework, we also allow for the relationship between hedge ratio volatility and past selective hedging cash flows to be a function of the beginning-of-quarter hedge ratio. In these robustness tests, also available upon request, we continue to find that hedge ratio volatility is positively related to past derivatives cash flows and that the relationship is robustly stronger for positive selective hedging cash flows, consistent with our managerial overconfidence hypothesis.

\section{Conclusions}

We add to the growing literature that documents the influence of managerial overconfidence in a variety of corporate finance settings, including investment and capital structure policy, mergers and acquisitions, security offerings and investment bank relationships, by showing that the effect of overconfidence also extends to corporate hedging decisions. We document a positive relationship between speculation and past speculative gains, without a corresponding relation between speculation and past speculative losses. This asymmetry supports the conjecture that the 
financial success of past speculative decisions increases managerial overconfidence, leading managers to elevate their levels of speculation, while losses do not reduce managerial overconfidence because managers tend to attribute failures to bad luck. Our findings provide the first evidence that corporate risk management practices are affected by behavioral managerial biases, and suggest that recognizing the presence of these biases will help bridge the gap between the theory and practice of corporate risk management. 


\section{Appendix 1: Variable Notations and Definitions}

Hedge Ratios:

HR1 - HR5 are the hedge ratios from one- to five-year maturities, respectively;

A3 is the aggregate hedge ratio that aggregates the hedge positions over one-, two-, and threeyear horizons, scaled by the expected production;

A3R is the aggregate hedge ratio that aggregates the hedge positions over one-, two-, and threeyear horizons, scaled by gold reserves;

A5R is the aggregate hedge ratio that aggregates the hedge positions over one-, two-, three-, four- and five-year horizons, scaled by gold reserves.

Hedge Ratio Volatility:

V1 - V5 are the quarterly volatilities of the one- through five-year hedge ratios, respectively. Quarterly volatility is the absolute value of the difference in the natural logarithms of the end-ofquarter and beginning-of-quarter hedge ratio levels.

V6 - V8 are the corresponding quarterly volatilities for A3, A3R, and A5R, respectively.

Derivatives Cash Flows:

CF are the total cash flows from derivatives positions (in \$ per ounce hedged) estimated as in Adam and Fernando (2006);

SCF and BCF are the selective and the benchmark cash flows, estimated as in Adam and Fernando (2006);

RBK is the change in the book value of the derivatives positions per ounce hedged (see Appendix 2).

Firm Characteristics:

SIZ is the logarithm of the market value of assets (\$ million); 
MB is the market-to-book ratio of assets;

DE is the ratio of book debt to book equity;

QCK is the quick ratio;

DIV is a dummy variable equal to one if the firm paid quarterly dividend;

RAT is a dummy variable equal to one if a firm reports a credit rating;

$\mathbf{Z}$ is the Altman's (1968) Z-score (higher value of $\mathbf{Z}$ corresponds to lower probability of bankruptcy).

DELTA_CEO (CFO) is the change in the dollar value of the CEO's (CFO's) wealth derived from ownership of stock and stock options in the firm when the firm's stock price changes by one percent, calculated according to the methodology of Core and Guay (2002). We calculate the aggregate delta of the executive's compensation as the sum of the deltas of the options holdings and the delta of the stock holdings.

VEGA_CEO (CFO) is the change in the dollar value of the CEO's (CFO's) wealth derived from ownership of stock and stock options in the firm when the annualized standard deviation of the firm's stock price changes by 0.01 , following Core and Guay (2002). We calculate the aggregate vega of the executive's compensation as the sum of the vegas of the executive's options holdings, following Coles, Daniel and Naveen (2006).

GLD is the change in the price of gold over the quarter; 


\section{Appendix 2: Calculation of Quarterly Derivatives Book Profits}

For the calculations of derivatives book profits, we use delta of the linear positions (which is equal to -1) and delta of option positions, which we back out from the total delta of the firm. We calculate the delta of option positions at the end of the quarter as the firm's total delta plus the number of linear contracts:

$$
\Delta_{t, \text { Option }}=\Delta_{t, \text { Total }}+N_{t, \text { Forward }}+N_{t, \text { Spot }}+N_{t, \text { Loan }}
$$

In (A1), $\Delta_{t, \text { Total }}$ is the total delta of the firm, $N_{t, \text { Forward }}$ is the number of forward contracts, $N_{t, \text { Spot }}$ is the number of spot contracts, and $N_{t, \text { Loan }}$ is the number of loan contracts. Then, for each quarter, we calculate the minimum of the two hedge positions,

$$
\begin{aligned}
& \operatorname{MIN}_{N L I N, t}=\min \left(N_{t, \text { Linear }}, N_{t-1, \text { Linear })}\right. \\
& \operatorname{MIN}_{N O P T, t}=\min \left(N_{t, \text { Option }}, N_{t-1, \text { Option })}\right.
\end{aligned}
$$

Above, $M I N_{N L I N, t}$ is the smaller of the beginning-of-quarter and end-of-quarter linear positions (forward plus spot plus loan) and $M I N_{N O P T, t}$ is the smaller of the beginning-of-quarter and end-ofquarter option positions. Obviously, at this step we lose observations where the size of the position is missing either at the beginning or at the end of the quarter.

Next, we calculate the delta $M \Delta_{t, \text { Option }}$ of option positions as the beginning-of-quarter delta $\Delta_{t-1, \text { Option }}$, divided by the beginning-of-quarter option position $N_{t-1, \text { option }}$, multiplied by the smaller of the beginning-of-quarter and the end-of-quarter positions:

$$
M \Delta_{t, \text { Option }}=\Delta_{t-1, \text { Option }} \cdot M I N_{N O P T, t} / N_{t-1, \text { Option }}
$$

If both option positions $N_{, t, \text { Option }}$ and $N_{t-1, \text { Option }}$ are zero, then delta is set to zero. Next, we use the option delta $M \Delta_{t, \text { Option }}$ to calculate the total book profits from linear positions $B K_{t, \text { Linear }}$, from option positions $B K_{t, \text { option }}$, and from all positions $B K_{t}$, where $G O L D_{t}$ is the price of one ounce of gold at the end of quarter $t$ : 


$$
\begin{gathered}
B K_{t, \text { Linear }}=M I N_{N L I N, t} \cdot\left(G O L D_{t-1}-G O L D_{t}\right) \\
B K_{t, \text { Option }}=M \Delta_{t, \text { Option }} \cdot\left(G O L D_{t-1}-G O L D_{t}\right) \cdot(-1) \\
B K_{t}=B K_{t, \text { Linear }}+B K_{t, \text { Option }}
\end{gathered}
$$

Finally, to adjust for the scale effect, we scale the total profits by the average size of the firm's position to obtain relative book profits from option positions $R B K_{t, \text { Option }}$, from linear

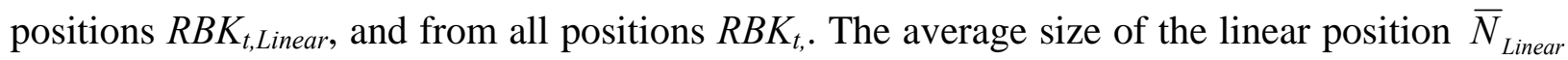
is equal to the average number of linear contracts reported by the firm over all quarters of the sample period in which a non-zero linear position is reported. The average size of the option positions $\bar{N}_{\text {Option }}$ is computed similarly.

$$
\begin{aligned}
& R B K_{t, \text { Option }}=B K_{t, \text { Option }} / \bar{N}_{\text {Option }} \\
& R B K_{t, \text { Linear }}=B K_{t, \text { Linear }} / \bar{N}_{\text {Linear }} \\
& R B K_{t}=R B K_{t, \text { Linear }}+R B K_{t, \text { Option }}
\end{aligned}
$$




\section{References}

Adam, Tim, 2002, Do Firms Use Derivatives to Reduce their Dependence on External Capital Markets? European Finance Review 6, 163-187.

Adam, Tim, and Chitru Fernando, 2006, Hedging, Speculation, and Shareholder Value, Journal of Financial Economics 81, 283-309.

Alizadeh, Sassan, Michael W. Brandt, and Francis X. Diebold, 2002, Range-Based Estimation of Stochastic Volatility Models, Journal of Finance 57, 1047-1092.

Altman, Edward I., 1968, Financial Ratios, Discriminant Analysis and the Prediction of Corporate Bankruptcy, Journal of Finance 23, 589-609.

Ang, Andrew, Robert J. Hodrick, Yuhang Xing, and Xiaoyan Zhang, 2006, The Cross-Section of Volatility and Expected Returns, Journal of Finance 61, 259-299.

Baker, Malcolm, Richard S. Ruback, and Jeffrey Wurgler, 2007, Behavioral Corporate Finance: A Survey, in The Handbook of Corporate Finance: Empirical Corporate Finance, edited by Espen Eckbo. Elsevier/North Holland, New York.

Barber, Brad M., and Terrance Odean, 2000, Trading is Hazardous to Your Wealth: The Common Stock Investment Performance of Individual Investors, Journal of Finance 55, 773806.

Beber, Alessandro, and Daniela Fabbri, 2010, Who Times the Foreign Exchange Market? Corporate Speculation and CEO Characteristics, Working Paper.

Ben-David, Itzhak, John R. Graham, and Campbell R. Harvey, 2007, Managerial Overconfidence and Corporate Policies, Working Paper.

Billett, Matthew T., and Yiming Qian, 2008, Are Overconfident CEOs Born or Made? Evidence of Self-Attribution Bias from Frequent Acquirers, Management Science 54, 1037-1051.

Bodnar, Gordon N., Gregory S. Hayt, and Richard C. Marston, 1998, Wharton Survey of Derivatives Usage by U.S. Non-Financial Firms, Financial Management 27, 70-91.

Breeden, Douglas, and S. Viswanathan, 1998, Why Do Firms Hedge? An Asymmetric Information Model, Working Paper.

Brown, Gregory W., Peter R. Crabb, and David Haushalter, 2006, Are Firms Successful at Selective Hedging? Journal of Business, 79, 2925-2949.

Campbell, Tim S. and William A. Kracaw, 1999, Optimal Speculation in the Presence of Costly External Financing. In “Corporate Risk: Strategies and Management,” Gregory Brown and Donald Chew, editors, Risk Publications, London. 
Daniel, Kent D., David Hirshleifer, and Avanidhar Subrahmanyam, 1998, Investor Psychology and Security Market Under- and Over-Reactions, Journal of Finance 53, 1839 - 1867.

DeMarzo, Peter M. and Darrell Duffie, 1995, Corporate Incentives for Hedging and Hedge Accounting, Review of Financial Studies 8, 743 - 772.

Dolde, Walter, 1993, The Trajectory of Corporate Financial Risk Management, Journal of Applied Corporate Finance 6, 33-41.

Fehle, Frank, and Sergey Tsyplakov, 2005, Dynamic Risk Management: Theory and Evidence, Journal of Financial Economics 78, 3-47.

Froot, Kenneth.A., David S. Scharfstein, and Jeremy C. Stein, 1993, Risk Management: Coordinating Corporate Investment and Financing Policies, Journal of Finance 48, 1629 - 1658.

Géczy, Christopher C., Bernadette A. Minton, and Catherine Schrand, 1997, Why Firms Use Currency Derivatives, Journal of Finance 52, 1323-1354.

Géczy, Christopher C., Bernadette A. Minton, and Catherine Schrand, 2007, Taking a View: Corporate Speculation, Governance and Compensation, Journal of Finance 62, 2405 - 2443.

Gervais, Simon, J.B. Heaton, and Terrance Odean, 2009, Overconfidence, Compensation Contracts, and Capital Budgeting, Journal of Finance 66, 1735 - 1777.

Gervais, Simon, and Terrance Odean, 2001, Learning to be Overconfident, Review of Financial Studies 14, 1-27.

Glaum, Martin, 2002, The Determinants of Selective Exchange-Risk Management - Evidence from German Non-Financial Corporations, Journal of Applied Corporate Finance 14, 108 - 121.

Goel, Anand, and Anjan Thakor, 2008, Overconfidence, CEO Selection and Corporate Governance, Journal of Finance 63, 2737- 2784.

Griffin, Dale and Amos Tversky, 1992, The Weighing of Evidence and the Determinants of Confidence, Cognitive Psychology 24, 411-435.

Haushalter, G. David, 2000, Financing Policy, Basis Risk, and Corporate Hedging: Evidence from Oil and Gas Producers, Journal of Finance 55, 107 - 152.

Heaton, J.B., 2002, Managerial Optimism and Corporate Finance, Financial Management, Summer, 33-45.

Heckman, James J., 1979, Sample Selection as a Specification Error, Econometrica 47, 153 161. 
Jin, Yanbo, and Philippe Jorion, 2006, Firm Value and Hedging: Evidence from U.S. Oil and Gas Producers, Journal of Finance 61, 893 - 919.

Leland, Hayne E., 1998, Agency Costs, Risk Management, and Capital Structure, Journal of Finance 53, 1213-1243.

Ljungqvist, Alexander, and William J. Wilhelm, Jr., 2005, Does Prospect Theory Explain IPO Market Behavior? Journal of Finance 60, 1759-1790.

Loughran, Tim, and Jay R. Ritter, 2002, Why Don't Issuers Get Upset About Leaving Money on the Table in IPOs? Review of Financial Studies 15, 413-443.

Malmendier, Ulrike, and Geoffrey Tate, 2005, CEO Overconfidence and Corporate Investment, Journal of Finance 60, 2661 - 2700.

Malmendier, Ulrike, and Geoffrey Tate, 2008, Who Makes Acquisitions? CEO Overconfidence and the Market's Reaction, Journal of Financial Economics 89, 20-43.

Malmendier, Ulrike, Geoffrey Tate, and Jon Yan, 2011, Overconfidence and Early-life Experience: The Effect of Managerial Traits on Corporate Financial Policies, Journal of Finance, forthcoming.

Mello, Antonio, and John Parsons, 2000, Hedging and Liquidity, Review of Financial Studies 13, $127-153$.

Miller, Dale T., and Michael Ross, 1975, Self-Serving Biases in the Attribution of Causality: Fact or Fiction? Psychological Bulletin 82, 213-225.

Roll, Richard, 1986, The Hubris Hypothesis of Corporate Takeovers, Journal of Business 59, 197-216.

Russo, J. Edward, and Paul J.H. Schoemaker, 1992, Managing Overconfidence, Sloan Management Review 33, 7-17.

Sautner, Zacharias, and Martin Weber, 2009, How Do Managers Behave in Stock Option Plans? Clinical Evidence from Exercise and Survey Data, Journal of Financial Research 32, 123-155.

Smith, Clifford W., and Rene M. Stulz, 1985, The Determinants of Firms' Hedging Policies, Journal of Financial and Quantitative Analysis 20, 391-405.

Stulz, René M., 1984, Optimal Hedging Policies, Journal of Financial and Quantitative Analysis $19,127-140$.

Stulz, René M., 1996, Rethinking Risk Management, Journal of Applied Corporate Finance 9, 8-24. 
Tufano, Peter, 1996, Who Manages Risk? An Empirical Examination of Risk Management Practices in the Gold Mining Industry, Journal of Finance 51, 1097-1137.

Tufano, Peter, 1998. The Determinants of Stock Price Exposure: Financial Engineering and the Gold Mining Industry, Journal of Finance 53, 1051-1052.

Working, Holbrook, 1962, New Concepts Concerning Futures Markets and Prices, American Economic Review 52, 431 - 459. 


\section{Table 1}

\section{Descriptive Statistics of Hedge Ratios, Hedge Volatility, Cash Flows, and Firm Characteristics}

Descriptive statistics are estimated on the pooled dataset. The sample consists of quarterly observations from 19891999 for a sample of 92 North American gold mining firms as reported in Gold and Silver Hedge Outlook. The table reports summary statistics for the following variables: hedge ratios of various maturities as well as aggregate hedge ratios estimated as the sum of the firm's derivatives positions in place in quarter $t$ (in ounces of gold), weighted by their respective deltas, scaled either by expected production or by reserves; hedge ratio volatilities estimated as the absolute value of the ratio of natural logarithms of the end-of-quarter to the beginning-of-quarter hedge ratio; total cash flows from derivatives positions per ounce hedged as well as selective and benchmark cash flows, which are estimated as in Adam and Fernando (2006); derivatives book profit equal to the change in the book value of the derivatives positions per ounce hedged (see Appendix 2 for calculation); change in the price of gold per ounce; firm size measured as the logarithm of the market value of assets; market-to-book ratio of assets; ratio of book debt to book equity; quick ratio; dividend dummy variable equal to one if the firm paid quarterly dividend; credit rating dummy variable equal to one if a firm reports a credit rating; and Altman's (1968) Z-score. Firm characteristics are from Compustat.

\begin{tabular}{lrrrrc}
\hline Variable & Mean & $\begin{array}{c}\text { Standard } \\
\text { Deviation }\end{array}$ & Minimum & Maximum & $\begin{array}{c}\text { Number of } \\
\text { Observations }\end{array}$ \\
\hline One-year hedge ratio & 0.2874 & 0.3179 & 0.0000 & 1.0000 & 1875 \\
Two-year hedge ratio & 0.1552 & 0.2418 & 0.0000 & 1.0000 & 1879 \\
Three-year hedge ratio & 0.0779 & 0.1722 & 0.0000 & 1.0000 & 1901 \\
Four-year hedge ratio & 0.0363 & 0.1135 & 0.0000 & 1.0000 & 1935 \\
Five-year hedge ratio & 0.0271 & 0.1092 & 0.0000 & 0.9990 & 1952 \\
Aggregate 3-yr. ratio, prod. & 0.1716 & 0.2402 & 0.0000 & 1.0000 & 1460 \\
Aggregate 3-yr. ratio, res. & 0.0465 & 0.0738 & 0.0000 & 0.6620 & 1460 \\
Aggregate 5-yr. ratio, res. & 0.0575 & 0.0961 & 0.0000 & 0.9857 & 1460 \\
Volatiliy, 1-yr. ratio & 1.2325 & 2.9044 & 0.0000 & 12.4055 & 1665 \\
Volatility, 2-yr. ratio & 1.2304 & 2.9902 & 0.0000 & 12.7594 & 1660 \\
Volatility, 3-yr. ratio & 0.8524 & 2.5275 & 0.0000 & 11.5129 & 1694 \\
Volatility, 4-yr. ratio & 0.8324 & 2.5702 & 0.0000 & 11.5129 & 1732 \\
Volatility, 5-yr. ratio & 0.5135 & 2.0428 & 0.0000 & 11.4742 & 1761 \\
Volatility, 3-yr. agg. ratio, prod. & 0.6838 & 2.0897 & 0.0000 & 11.5000 & 1253 \\
Volatility, 3-yr. agg. ratio, res. & 0.6477 & 1.8500 & 0.0000 & 10.5740 & 1262 \\
Volatility, 5-yr. agg. ratio, res. & 0.6867 & 1.8970 & 0.0000 & 11.2149 & 1304 \\
Total derivative cash flow & 4.8063 & 16.2041 & -95.9039 & 180.1249 & 1788 \\
Selective cash flow & 0.3680 & 10.5898 & -66.7713 & 201.8647 & 1801 \\
Benchmark cash flow & 4.4377 & 16.7540 & -90.4059 & 180.1249 & 1788 \\
Derivative book profit & 2.1401 & 16.4882 & -181.3730 & 106.0881 & 1750 \\
Change in the price of gold & -3.0569 & 17.7753 & -48.9000 & 52.0000 & 1781 \\
Size & 5.5771 & 1.7608 & 1.0460 & 9.3604 & 1858 \\
Market-to-Book ratio & 1.9381 & 1.1137 & 0.2985 & 9.0819 & 1647 \\
Debt-to-Equity ratio & 0.4619 & 1.0772 & 0.0000 & 21.2707 & 1205 \\
Quick ratio & 4.2476 & 9.7254 & 0.0065 & 141.5172 & 1161 \\
Dividend dummy & 0.4701 & 0.4993 & 0.0000 & 1.0000 & 1289 \\
Rating dummy & 0.2454 & 0.4305 & 0.0000 & 1.0000 & 1312 \\
Altman's Z-score & 4.9900 & 13.5111 & -22.8560 & 126.8310 & 1618 \\
\hline
\end{tabular}




\section{Table 2}

\section{Correlations Across Hedge Ratios and Across Hedge Ratio Volatilities}

Correlations are estimated on the pooled dataset. The sample consists of quarterly observations over 1989-1999 for a sample of 92 North American gold mining firms as reported in Gold and Silver Hedge Outlook. HR1 - HR5 are hedge ratios with one- to five- year maturity, respectively; VI - V5 are their respective volatilities; $A 3$ is the aggregate 3-year hedge ratio scaled by expected production, $A 3 R$ is the aggregate 3-year hedge ratio scaled by reserves, and $A 5 R$ is the aggregate five-year hedge ratio scaled by reserves, and $V 6-V 8$ are their respective volatilities. ${ }^{* * *},{ }^{* *}$, and $*$ indicate significance at $1 \%, 5 \%$, and $10 \%$ level, respectively.

Panel A: Correlations of the hedge ratios

\begin{tabular}{|c|c|c|c|c|c|c|c|c|}
\hline & HR1 & HR2 & HR3 & HR4 & HR5 & A3 & A3R & A5R \\
\hline HR1 & 1.0000 & & & & & & & \\
\hline HR2 & $0.5841^{* * *}$ & 1.0000 & & & & & & \\
\hline HR3 & $0.4208^{* * *}$ & $0.7195^{* * *}$ & 1.0000 & & & & & \\
\hline HR4 & $0.2591^{* * *}$ & $0.4611^{* * *}$ & $0.6717^{* * *}$ & 1.0000 & & & & \\
\hline HR5 & $0.1646^{* * *}$ & $0.2625^{* * *}$ & $0.4029^{* * *}$ & $0.5356^{* * *}$ & 1.0000 & & & \\
\hline A3 & $0.7462^{* * *}$ & $0.9340^{* * *}$ & $0.8608^{* * *}$ & $0.5576^{* * * *}$ & $0.3345^{* * *}$ & 1.0000 & & \\
\hline A3R & $0.6457^{* * *}$ & $0.6901^{* * * *}$ & $0.5993^{* * *}$ & $0.4317^{* * *}$ & $0.2919^{* * *}$ & $0.7750^{* * * *}$ & 1.0000 & \\
\hline A5R & $0.5721^{\text {**** }}$ & $0.6381^{\text {**** }}$ & $0.6387^{\text {**** }}$ & $0.5767^{* * *}$ & $0.4904^{* * *}$ & $0.7366^{* * *}$ & $0.9194^{* * *}$ & 1.0000 \\
\hline
\end{tabular}

Panel B: Correlations of hedge ratio volatilities

\begin{tabular}{|c|c|c|c|c|c|c|c|c|}
\hline & V1 & $\mathrm{V} 2$ & V3 & V4 & V5 & V6 & V7 & $\mathrm{V8}$ \\
\hline V1 & 1.0000 & & & & & & & \\
\hline $\mathrm{V} 2$ & $0.2773^{* * *}$ & 1.0000 & & & & & & \\
\hline V3 & $0.1105^{* * *}$ & $0.2754^{* * *}$ & 1.0000 & & & & & \\
\hline V4 & $0.0426^{*}$ & $0.0556^{* *}$ & $0.1512^{* * *}$ & 1.0000 & & & & \\
\hline V5 & 0.0380 & $0.0542^{* *}$ & $0.1226^{* * *}$ & $0.3893^{* * *}$ & 1.0000 & & & \\
\hline V6 & $0.8096^{* * *}$ & $0.5182^{* * *}$ & $0.3571^{* * *}$ & $0.0623^{* *}$ & $0.0900^{* * *}$ & 1.0000 & & \\
\hline V7 & $0.7703^{* * *}$ & $0.3981^{* * *}$ & $0.2248^{* * *}$ & $0.1044^{* *}$ & $0.1142^{* * *}$ & $0.9894^{* * *}$ & 1.0000 & \\
\hline V8 & $0.7644^{* * *}$ & $0.3618^{* * * *}$ & $0.2129^{\text {**** }}$ & $0.0927^{* * * *}$ & $0.1020^{* * *}$ & $0.9785^{* * *}$ & $0.9827^{* * * *}$ & 1.0000 \\
\hline
\end{tabular}


Table 3

\section{Relationship between Speculation and Past Total Derivatives Cash Flows}

The table presents the results of the panel regressions with firm fixed effects. The dependent variable is the volatility of the hedge ratio. Hedge ratio volatility is estimated as the absolute value of the difference in the logs of the hedge ratio in the end and the beginning of the quarter. The independent variables are as follows: $C F$ is the total derivatives cash flow in the previous quarter; $R B K$ is the change in the book value of derivatives positions in the previous quarter. Seasonal dummies are included in each of the models. The regressions include the following firm characteristics as control variables: $S I Z$, firm size measured as the logarithm of the market value of assets; $M B$, market-to-book ratio of assets; $D E$, ratio of book debt to book equity; $Q C K$, quick ratio; $D I V$, dummy variable equal to one if the firm paid quarterly dividend; $R A T$, dummy variable equal to one if a firm reports a credit rating; and $Z$, Altman's Z-score. ${ }^{* * *}, * *, *$ indicate significance at the $1 \%, 5 \%$ and $10 \%$ levels, respectively. Robust t-statistics corrected for cluster effects are reported in parentheses.

\begin{tabular}{|c|c|c|c|c|c|c|c|c|}
\hline & \multicolumn{2}{|c|}{$\begin{array}{c}\text { Volatility of } \\
\text { one-year hedge ratio }\end{array}$} & \multicolumn{2}{|c|}{$\begin{array}{c}\text { Volatility of } \\
\text { aggregate 3-year ratio } \\
\text { scaled by production }\end{array}$} & \multicolumn{2}{|c|}{$\begin{array}{c}\text { Volatility of } \\
\text { aggregate 3-year ratio } \\
\text { scaled by reserves }\end{array}$} & \multicolumn{2}{|c|}{$\begin{array}{c}\text { Volatility of } \\
\text { aggregate 5-year ratio } \\
\text { scaled by reserves }\end{array}$} \\
\hline & $(1)$ & (2) & (3) & (4) & (5) & (6) & (7) & (8) \\
\hline Intercept & $\begin{array}{l}0.9315^{* * *} \\
(5.29)\end{array}$ & $\begin{array}{r}2.9375 \\
(1.10)\end{array}$ & $\begin{array}{l}0.7202^{* * *} \\
(5.46)\end{array}$ & $\begin{array}{c}3.7069^{*} \\
(1.93)\end{array}$ & $\begin{array}{l}0.6400 \\
(4.75)\end{array}$ & $\begin{array}{r}1.6145 \\
(0.80)\end{array}$ & $\begin{array}{l}0.74488^{* * *} \\
(6.40)\end{array}$ & $\begin{array}{r}1.2300 \\
(0.77)\end{array}$ \\
\hline CF & $\begin{array}{l}0.023^{* * *} \\
(3.60)\end{array}$ & $\begin{array}{l}0.0181^{* *} \\
(2.24)\end{array}$ & $\begin{array}{l}0.0213^{* * *} \\
(3.03)\end{array}$ & $\begin{array}{r}0.0113 \\
(1.53)\end{array}$ & $\begin{array}{l}0.0237^{* * *} \\
(3.54)\end{array}$ & $\begin{array}{l}0.0209^{* * *} \\
(2.95)\end{array}$ & $\begin{array}{l}0.0164^{* * *} \\
(3.53)\end{array}$ & $\begin{array}{l}0.0150 \text { ** } \\
(2.89)\end{array}$ \\
\hline RBK & $\begin{array}{r}0.0019 \\
(0.91)\end{array}$ & $\begin{array}{r}-0.0017 \\
(-0.72)\end{array}$ & $\begin{array}{r}-0.0011 \\
(-0.69)\end{array}$ & $\begin{array}{r}-0.0017 \\
(-0.74)\end{array}$ & $\begin{array}{r}-0.0020 \\
(-1.29)\end{array}$ & $\begin{array}{r}-0.0038 \\
(-1.68)\end{array}$ & $\begin{array}{r}-0.0003 \\
(-0.23)\end{array}$ & $\begin{array}{r}-0.0021 \\
(-0.97)\end{array}$ \\
\hline SIZ & & $\begin{array}{r}-0.1817 \\
(-0.39)\end{array}$ & & $\begin{array}{r}-0.3584 \\
(-1.18)\end{array}$ & & $\begin{array}{r}-0.0319 \\
(-0.09)\end{array}$ & & $\begin{array}{r}0.0572 \\
(0.20)\end{array}$ \\
\hline Z & & $\begin{array}{c}0.0730^{*} \\
(1.36)\end{array}$ & & $\begin{array}{r}0.0787 \\
(1.64)\end{array}$ & & $\begin{array}{r}0.0458 \\
(1.29)\end{array}$ & & $\begin{array}{c}0.0490 * \\
(1.91)\end{array}$ \\
\hline QCK & & $\begin{array}{r}0.0212 \\
(0.27)\end{array}$ & & $\begin{array}{r}-0.0208 \\
(-0.57)\end{array}$ & & $\begin{array}{r}-0.0342 \\
(-1.24)\end{array}$ & & $\begin{array}{r}-0.0127 \\
(-0.44)\end{array}$ \\
\hline MB & & $\begin{array}{l}-0.55944^{* * *} \\
(-2.64)\end{array}$ & & $\begin{array}{l}-0.2617^{*} \\
(-1.76)\end{array}$ & & $\begin{array}{r}-0.2153 \\
(-1.53)\end{array}$ & & $\begin{array}{l}-0.2190^{* *} \\
(-1.98)\end{array}$ \\
\hline $\mathrm{DE}$ & & $\begin{array}{r}-0.1862 \\
(-1.12)\end{array}$ & & $\begin{array}{r}-0.2467 \\
(-1.28)\end{array}$ & & $\begin{array}{l}-0.4726 \\
(-4.46)\end{array}$ & & $\begin{array}{l}-0.3233^{* *} \\
(-2.32)\end{array}$ \\
\hline DIV & & $\begin{array}{r}0.2905 \\
(0.68)\end{array}$ & & $\begin{array}{r}-0.2261 \\
(-0.70)\end{array}$ & & $\begin{array}{r}-0.2401 \\
(-1.07)\end{array}$ & & $\begin{array}{l}-0.6023^{* * *} \\
(-3.52)\end{array}$ \\
\hline RAT & & $\begin{array}{r}-0.3583 \\
(-0.68)\end{array}$ & & $\begin{array}{r}-0.0684 \\
(-0.19)\end{array}$ & & $\begin{array}{r}-0.1324 \\
(-0.43)\end{array}$ & & $\begin{array}{r}-0.2063 \\
(-0.77)\end{array}$ \\
\hline Dummies & YES & YES & YES & YES & YES & YES & YES & YES \\
\hline $\mathrm{R}^{2}$ & 0.0304 & 0.0382 & 0.0263 & 0.0330 & 0.0379 & 0.0519 & 0.0204 & 0.0364 \\
\hline F-statistic & 4.70 & 1.62 & 3.85 & 1.64 & 3.44 & 5.82 & 3.27 & 2.84 \\
\hline Observations & 1112 & 638 & 788 & 465 & 854 & 529 & 1005 & 621 \\
\hline Clusters & 84 & 65 & 65 & 48 & 61 & 51 & 63 & 53 \\
\hline
\end{tabular}




\section{Table 4}

\section{Relationship between Speculation and Past Selective Hedging Cash Flows}

The table presents the results of the panel regressions with firm fixed effects. The dependent variable is the volatility of the hedge ratio. Hedge ratio volatility is estimated as the absolute value of the difference in the logs of the hedge ratio in the end and the beginning of the quarter. The independent variables are as follows: $S C F$ is the selective hedging cash flow in the previous quarter; $B C F$ is the benchmark cash flow in the previous quarter; $R B K$ is the change in the book value of derivatives positions in the previous quarter. Seasonal dummies are included in each of the models. The regressions include the following firm characteristics as control variables: SIZ, firm size measured as the logarithm of the market value of assets; $M B$, market-to-book ratio of assets; $D E$, ratio of book debt to book equity; $Q C K$, quick ratio; $D I V$, dummy variable equal to one if the firm paid quarterly dividend; $R A T$, dummy variable equal to one if a firm reports a credit rating; and $Z$, Altman's Z-score. ***, **, * indicate significance at the $1 \%, 5 \%$ and $10 \%$ levels, respectively. Robust t-statistics corrected for cluster effects are reported in parentheses.

\begin{tabular}{|c|c|c|c|c|c|c|c|c|}
\hline & \multicolumn{2}{|c|}{$\begin{array}{c}\text { Volatility of } \\
\text { one-year hedge ratio }\end{array}$} & \multicolumn{2}{|c|}{$\begin{array}{c}\text { Volatility of } \\
\text { aggregate 3-year ratio } \\
\text { scaled by production }\end{array}$} & \multicolumn{2}{|c|}{$\begin{array}{c}\text { Volatility of } \\
\text { aggregate 3-year ratio } \\
\text { scaled by reserves }\end{array}$} & \multicolumn{2}{|c|}{$\begin{array}{c}\text { Volatility of } \\
\text { aggregate 5-year ratio } \\
\text { scaled by reserves }\end{array}$} \\
\hline & (1) & (2) & (3) & (4) & $\begin{array}{l}(5) \\
\end{array}$ & (6) & $\begin{array}{l}(7) \\
\end{array}$ & $\begin{array}{l}(8) \\
\end{array}$ \\
\hline Intercept & $\begin{array}{l}0.9468^{* * *} \\
(5.50)\end{array}$ & $\begin{array}{r}2.9597 \\
(1.11)\end{array}$ & $\begin{array}{l}0.7154^{* * *} \\
(5.39)\end{array}$ & $\begin{array}{l}3.9226^{* *} \\
(2.02)\end{array}$ & $\begin{array}{l}0.6301^{* * * *} \\
(4.65)\end{array}$ & $\begin{array}{r}1.7182 \\
(0.84)\end{array}$ & $\begin{array}{l}0.7338^{* * *} \\
(6.31)\end{array}$ & $\begin{array}{r}1.3219 \\
(0.82)\end{array}$ \\
\hline SCF & $\begin{array}{c}0.0174^{*} \\
(1.66)\end{array}$ & $\begin{array}{r}0.0199 \\
(1.54)\end{array}$ & $\begin{array}{l}0.0237^{* * *} \\
(2.97)\end{array}$ & $\begin{array}{l}0.0210^{* *} \\
(2.80)\end{array}$ & $\begin{array}{l}0.0273^{* * *} \\
(3.43)\end{array}$ & $\begin{array}{l}0.0263^{* * *} \\
(3.45)\end{array}$ & $\begin{array}{l}0.0202^{* * *} \\
(3.14)\end{array}$ & $\begin{array}{l}0.0212^{* * *} \\
(3.02)\end{array}$ \\
\hline $\mathrm{BCF}$ & $\begin{array}{l}0.0249 \\
(3.56)\end{array}$ & $\begin{array}{c}0.0173 \\
(2.15)\end{array}$ & $\begin{array}{l}0.0209 \\
(2.95)\end{array}$ & $\begin{array}{r}0.0092 \\
(1.26)\end{array}$ & $\begin{array}{l}0.0224 \\
(3.39)\end{array}$ & $\begin{array}{c}0.0180 \\
(2.50)\end{array}$ & $\begin{array}{l}0.0153^{* * * *} \\
(3.40)\end{array}$ & $\begin{array}{c}0.0124 \\
(2.49)\end{array}$ \\
\hline RBK & $\begin{array}{r}0.0021 \\
(0.96)\end{array}$ & $\begin{array}{r}-0.0117 \\
(-0.73)\end{array}$ & $\begin{array}{r}-0.0012 \\
(-0.72)\end{array}$ & $\begin{array}{r}-0.0020 \\
(-0.86)\end{array}$ & $\begin{array}{r}-0.0021 \\
(-1.36)\end{array}$ & $\begin{array}{c}-0.0040^{*} \\
(-1.77)\end{array}$ & $\begin{array}{r}-0.0004 \\
(-0.30)\end{array}$ & $\begin{array}{r}-0.0023 \\
(-1.08)\end{array}$ \\
\hline SIZ & & $\begin{array}{r}-0.1851 \\
(-0.40)\end{array}$ & & $\begin{array}{r}-0.3901 \\
(-1.28)\end{array}$ & & $\begin{array}{r}-0.0454 \\
(-0.13)\end{array}$ & & $\begin{array}{r}0.0413 \\
(0.14)\end{array}$ \\
\hline $\mathrm{Z}$ & & $\begin{array}{r}0.0736 \\
(1.37)\end{array}$ & & $\begin{array}{r}0.0825 \\
(1.70)\end{array}$ & & $\begin{array}{r}0.0493 \\
(1.36)\end{array}$ & & $\begin{array}{c}0.0514 \\
(1.96)\end{array}$ \\
\hline QCK & & $\begin{array}{r}0.0205 \\
(0.26)\end{array}$ & & $\begin{array}{r}-0.0239 \\
(-0.65)\end{array}$ & & $\begin{array}{r}-0.0382 \\
(-1.39)\end{array}$ & & $\begin{array}{r}-0.0156 \\
(-0.54)\end{array}$ \\
\hline MB & & $\begin{array}{l}-0.5615^{* * *} \\
(-2.64)\end{array}$ & & $\begin{array}{c}-0.2738^{*} \\
(-1.87)\end{array}$ & & $\begin{array}{c}-0.2282^{*} \\
(-1.64)\end{array}$ & & $\begin{array}{l}-0.2202^{* *} \\
(-2.00)\end{array}$ \\
\hline $\mathrm{DE}$ & & $\begin{array}{r}-0.1871 \\
(-1.12)\end{array}$ & & $\begin{array}{r}-0.2505 \\
(-1.31)\end{array}$ & & $\begin{array}{l}-0.4789 \\
(-4.65)\end{array}$ & & $\begin{array}{c}-0.32688^{* *} \\
(-2.36)\end{array}$ \\
\hline DIV & & $\begin{array}{r}0.2899 \\
(0.68)\end{array}$ & & $\begin{array}{r}-0.2042 \\
(-0.67)\end{array}$ & & $\begin{array}{r}-0.2401 \\
(-1.10)\end{array}$ & & $\begin{array}{l}-0.5993^{* * *} \\
(-3.58)\end{array}$ \\
\hline RAT & & $\begin{array}{r}-0.3553 \\
(-0.67)\end{array}$ & & $\begin{array}{r}-0.0431 \\
(-0.12)\end{array}$ & & $\begin{array}{r}-0.1203 \\
(-0.40)\end{array}$ & & $\begin{array}{r}-0.1940 \\
(-0.73)\end{array}$ \\
\hline Dummies & YES & YES & YES & YES & YES & YES & YES & YES \\
\hline$\overline{\mathrm{R}^{2}}$ & 0.0308 & 0.0384 & 0.0267 & 0.0349 & 0.0399 & 0.0567 & 0.0229 & 0.0434 \\
\hline F-statistic & 3.88 & 1.50 & 3.62 & 1.98 & 3.15 & 6.15 & 3.02 & 2.90 \\
\hline Observations & 1112 & 638 & 788 & 465 & 854 & 529 & 1005 & 621 \\
\hline Clusters & 84 & 65 & 65 & 48 & 61 & 51 & 63 & 53 \\
\hline
\end{tabular}




\section{Table 5}

Determinants of Hedging Activity: First Stage of the Two-Step Heckman Regression With Selection The table reports the results of the PROBIT model. The dependent variable is the hedging activity dummy equal to zero if (1) either the firm had zero hedge ratios in both the beginning and the end of quarter $t$; or (2) the firm had zero cash flows from hedging operations in quarter $t-1$. The independent variables are: firm size measured as the logarithm of the market value of assets; market-to-book ratio of assets; ratio of book debt to book equity; quick ratio; dummy variable equal to one if the firm paid quarterly dividend; dummy variable equal to one if a firm reports a credit rating; and Altman's Z-score. Z-statistics are in parentheses and ${ }^{* * *},{ }^{* *}$, and * indicate significance at $1 \%$, $5 \%$, and $10 \%$ level, respectively.

\begin{tabular}{|c|c|}
\hline & Probability of Hedging \\
\hline Intercept & $\begin{array}{c}0.5409 \text { * } \\
(2.10)\end{array}$ \\
\hline Size & $\begin{array}{c}0.2403^{*} \\
(4.50)\end{array}$ \\
\hline Market-to-book & $\begin{array}{c}-0.3013 \\
(-3.91)\end{array}$ \\
\hline Debt-to-Equity & $\begin{array}{c}-0.2064 \\
(-2.82)\end{array}$ \\
\hline Quick ratio & $\begin{array}{c}-0.0789 \\
(-4.98)\end{array}$ \\
\hline Dividend dummy & $\begin{array}{l}-0.487^{\text {t*t+ }} \\
(-3.25)\end{array}$ \\
\hline Credit rating dummy & $\begin{array}{r}0.0916 \\
(0.61)\end{array}$ \\
\hline Altman Z-score & $\begin{array}{r}-0.0193 \\
(-1.25)\end{array}$ \\
\hline Pseudo-R ${ }^{2}$ & 0.1051 \\
\hline $\mathrm{Chi}^{2}$ & 86.57 \\
\hline Observations & 792 \\
\hline
\end{tabular}




\section{Table 6}

\section{Determinants of Hedge Ratio Volatility Conditional on Hedging Activity:}

Second Stage of the Two-Step Heckman Regression with Selection

The table reports the results of the second stage of the two-step Heckman procedure. In the first stage (see Table 6), we estimate the likelihood of hedging activity in a given quarter. In the second stage, we estimate the relationship between hedge ratio volatility in quarter $t$ versus cash flows and book profits from derivatives positions in quarter $t$ 1 , conditional on hedging activity. Hedge ratio volatility is estimated as the absolute value of the difference in the logs of the hedge ratio from the beginning to the end of the quarter. $C F$ is the total derivatives cash flow; $S C F$ is selective hedging cash flow; $B C F$ is the benchmark cash flow; $R B K$ is the change in the book value of derivatives positions. Seasonal dummies are included in each model. The regressions control for the following firm characteristics: firm size measured as the logarithm of the market value of assets; market-to-book ratio of assets; ratio of book debt to book equity; quick ratio; dividend dummy variable equal to one if the firm paid quarterly dividend; credit rating dummy variable equal to one if a firm reports a credit rating; and Altman's Z-score. The regressions include the Inverse Mills ratio estimated on the first stage of the Heckman procedure. $* * *, * *, *$ indicate significance at the $1 \%, 5 \%$ and $10 \%$ levels, respectively. Robust t-statistics corrected for cluster effects are reported in parentheses.

\begin{tabular}{|c|c|c|c|c|c|c|c|c|}
\hline & \multicolumn{2}{|c|}{$\begin{array}{c}\text { Volatility of } \\
\text { one-year hedge ratio }\end{array}$} & \multicolumn{2}{|c|}{$\begin{array}{c}\text { Volatility of } \\
\text { aggregate 3-year ratio } \\
\text { scaled by production }\end{array}$} & \multicolumn{2}{|c|}{$\begin{array}{c}\text { Volatility of } \\
\text { aggregate 3-year ratio } \\
\text { scaled by reserves }\end{array}$} & \multicolumn{2}{|c|}{$\begin{array}{c}\text { Volatility of } \\
\text { aggregate 5-year ratio } \\
\text { scaled by reserves }\end{array}$} \\
\hline & (1) & (2) & (3) & (4) & (5) & (6) & (7) & (8) \\
\hline Intercept & $\begin{array}{l}4.4363^{* * *} \\
(2.99)\end{array}$ & $\begin{array}{l}4.4151^{* * *} \\
(2.94)\end{array}$ & $\begin{array}{r}2.3099 \\
(1.13)\end{array}$ & $\begin{array}{r}2.2593 \\
(1.11)\end{array}$ & $\begin{array}{l}3.1157^{* *} \\
(2.41)\end{array}$ & $\begin{array}{l}3.0198^{* *} \\
(2.32)\end{array}$ & $\begin{array}{l}2.5783^{* *} \\
(2.37)\end{array}$ & $\begin{array}{l}2.437^{* *} \\
(2.22)\end{array}$ \\
\hline $\mathrm{CF}$ & $\begin{array}{c}0.00221 \\
(2.53)\end{array}$ & & $\begin{array}{l}0.0234^{* *} \\
(2.35)\end{array}$ & & $\begin{array}{l}0.0215 \\
(3.39)\end{array}$ & & $\begin{array}{l}0.0161 \\
(3.07)\end{array}$ & \\
\hline SCF & & $\begin{array}{c}0.0238^{*} \\
(1.96)\end{array}$ & & $\begin{array}{l}0.0288^{* *} \\
(2.67)\end{array}$ & & $\begin{array}{l}0.0263^{* * * *} \\
(4.10)\end{array}$ & & $\begin{array}{l}0.0224 * * * \\
(3.68)\end{array}$ \\
\hline BCF & & $\begin{array}{l}0.0212 \\
(2.29)\end{array}$ & & $\begin{array}{l}0.0223^{* *} \\
(2.27)\end{array}$ & & $\begin{array}{l}0.0184^{* * *} \\
(2.73)\end{array}$ & & $\begin{array}{l}0.0129 \text { ** } \\
(2.49)\end{array}$ \\
\hline RBK & $\begin{array}{r}-0.0006 \\
(-0.31)\end{array}$ & $\begin{array}{r}-0.0007 \\
(-0.32)\end{array}$ & $\begin{array}{r}-0.0023 \\
(-0.84)\end{array}$ & $\begin{array}{r}-0.0025 \\
(-0.90)\end{array}$ & $\begin{array}{r}-0.0025 \\
(-1.18)\end{array}$ & $\begin{array}{r}-0.0026 \\
(-1.24)\end{array}$ & $\begin{array}{r}-0.0016 \\
(-0.75)\end{array}$ & $\begin{array}{r}-0.0017 \\
(-0.83)\end{array}$ \\
\hline Inverse Mills & -3.7381 & -3.7044 & -1.2069 & -1.0787 & -3.1570 & -2.9739 & -1.5532 & -1.3087 \\
\hline Ratio & $(-1.38)$ & $(-1.36)$ & $(-0.29)$ & $(-0.26)$ & $(-1.25)$ & $(-1.17)$ & $(-0.82)$ & $(-0.69)$ \\
\hline Controls & YES & YES & YES & YES & YES & YES & YES & YES \\
\hline Dummies & YES & YES & YES & YES & YES & YES & YES & YES \\
\hline$\overline{\mathrm{R}^{2}}$ & 0.0769 & 0.0770 & 0.0738 & 0.0749 & 0.0879 & 0.0916 & 0.0738 & 0.0786 \\
\hline F-statistic & 5.32 & 4.96 & 2.97 & 2.73 & 3.10 & 3.33 & 2.44 & 2.99 \\
\hline Observations & 585 & 585 & 442 & 442 & 526 & 526 & 614 & 614 \\
\hline Clusters & 53 & 53 & 42 & 42 & 51 & 51 & 53 & 53 \\
\hline
\end{tabular}


Table 7

Determinants of Hedge Ratio Volatility Conditional on Hedging Activity:

Controlling for Managerial Compensation (CEO)

The table reports the results of the second stage of the two-step Heckman procedure. In the first stage (see Table 6), we estimate the likelihood of hedging activity in a given quarter. In the second stage, we estimate the relationship between hedge ratio volatility in quarter $t$ versus cash flows and book profits from derivatives positions in quarter $t$ 1 , conditional on hedging activity. Hedge ratio volatility is estimated as the absolute value of the difference in the logs of the hedge ratio from the beginning to the end of the quarter. $C F$ is the total derivatives cash flow; $S C F$ is selective hedging cash flow; $B C F$ is the benchmark cash flow; DELTA_CEO and VEGA_CEO are the managerial compensation sensitivities for the CEO. The regressions include the Inverse Mills ratio estimated on the first stage of the Heckman procedure. $* * *, * *$, * indicate significance at the $1 \%, 5 \%$ and $10 \%$ levels, respectively. Robust tstatistics corrected for cluster effects are reported in parentheses.

\begin{tabular}{|c|c|c|c|c|c|c|c|c|}
\hline & \multicolumn{2}{|c|}{$\begin{array}{c}\text { Volatility of } \\
\text { one-year ratio }\end{array}$} & \multicolumn{2}{|c|}{$\begin{array}{c}\text { Volatility of } \\
\text { aggregate 3-year ratio } \\
\text { scaled by production }\end{array}$} & \multicolumn{2}{|c|}{$\begin{array}{c}\text { Volatility of } \\
\text { aggregate 3-year ratio } \\
\text { scaled by reserves }\end{array}$} & \multicolumn{2}{|c|}{$\begin{array}{c}\text { Volatility of } \\
\text { aggregate 5-year ratio } \\
\text { scaled by reserves }\end{array}$} \\
\hline & (1) & (2) & (3) & (4) & (5) & (6) & (7) & (8) \\
\hline Intercept & $\begin{array}{r}0.2460 \\
(0.21)\end{array}$ & $\begin{array}{r}0.2453 \\
(0.21)\end{array}$ & $\begin{array}{r}1.4696 \\
(0.81)\end{array}$ & $\begin{array}{r}1.4616 \\
(0.81)\end{array}$ & $\begin{array}{r}1.0222 \\
(0.78)\end{array}$ & $\begin{array}{r}1.0261 \\
(0.78)\end{array}$ & $\begin{array}{r}1.7445 \\
(1.26)\end{array}$ & $\begin{array}{r}1.7351 \\
(1.24)\end{array}$ \\
\hline $\mathrm{CF}$ & $\begin{array}{r}0.0159 \\
(1.35)\end{array}$ & & $\begin{array}{r}0.0183 \\
(1.19)\end{array}$ & & $\begin{array}{l}0.0161 \text { ** } \\
(2.08)\end{array}$ & & $\begin{array}{c}0.0171 \\
(2.82)\end{array}$ & \\
\hline SCF & & $\begin{array}{r}0.0143 \\
(0.79)\end{array}$ & & $\begin{array}{r}0.0169 \\
(0.81)\end{array}$ & & $\begin{array}{c}0.01822^{* *} \\
(2.03)\end{array}$ & & $\begin{array}{c}0.0212 \text { ** } \\
(2.74)\end{array}$ \\
\hline BCF & & $\begin{array}{r}0.0164 \\
(1.47)\end{array}$ & & $\begin{array}{r}0.0186 \\
(1.25)\end{array}$ & & $\begin{array}{l}0.0155^{* *} \\
(2.05)\end{array}$ & & $\begin{array}{l}0.0159 \text { ** } \\
(2.72)\end{array}$ \\
\hline DELTA_CEO & $\begin{array}{r}-0.1665 \\
(-0.96)\end{array}$ & $\begin{array}{r}-0.1638 \\
(-0.95)\end{array}$ & $\begin{array}{r}-0.1755 \\
(-0.88)\end{array}$ & $\begin{array}{r}-0.1725 \\
(-0.91)\end{array}$ & $\begin{array}{r}-0.1250 \\
(-1.12)\end{array}$ & $\begin{array}{r}-0.1291 \\
(-1.20)\end{array}$ & $\begin{array}{r}-0.1260 \\
(-1.18)\end{array}$ & $\begin{array}{r}-0.1346 \\
(-1.31)\end{array}$ \\
\hline VEGA_CEO & $\begin{array}{r}0.2002 \\
(1.18)\end{array}$ & $\begin{array}{r}0.1963 \\
(1.18)\end{array}$ & $\begin{array}{r}0.0822 \\
(0.35)\end{array}$ & $\begin{array}{r}0.0788 \\
(0.35)\end{array}$ & $\begin{array}{r}0.0738 \\
(0.53)\end{array}$ & $\begin{array}{r}0.0791 \\
(0.58)\end{array}$ & $\begin{array}{r}0.0176 \\
(0.12)\end{array}$ & $\begin{array}{r}0.0291 \\
(0.19)\end{array}$ \\
\hline $\begin{array}{l}\text { Inverse Mills } \\
\text { Ratio }\end{array}$ & $\begin{array}{r}0.1638 \\
(1.76)\end{array}$ & $\begin{array}{r}3.1772 \\
(1.75)\end{array}$ & $\begin{array}{r}1.9141 \\
(1.09)\end{array}$ & $\begin{array}{r}1.9362 \\
(1.11)\end{array}$ & $\begin{array}{r}1.0782 \\
(0.87)\end{array}$ & $\begin{array}{r}1.0549 \\
(0.86)\end{array}$ & $\begin{array}{r}0.2416 \\
(0.32)\end{array}$ & $\begin{array}{r}0.2517 \\
(0.34)\end{array}$ \\
\hline$\overline{\mathrm{R}^{2}}$ & 0.0545 & 0.0544 & 0.037 & 0.0371 & 0.0407 & 0.0409 & 0.0466 & 0.0478 \\
\hline F-statistic & 2.08 & 1.64 & 1.46 & 1.16 & 2.19 & 1.91 & 3.41 & 3.30 \\
\hline Observations & 146 & 146 & 106 & 106 & 127 & 127 & 155 & 155 \\
\hline Clusters & 41 & 41 & 31 & 31 & 39 & 39 & 42 & 42 \\
\hline
\end{tabular}




\section{Table 8}

Determinants of Hedge Ratio Volatility Conditional on Hedging Activity: Controlling for Managerial Compensation (CFO)

The table reports the results of the second stage of the two-step Heckman procedure. In the first stage (see Table 6), we estimate the likelihood of hedging activity in a given quarter. In the second stage, we estimate the relationship between hedge ratio volatility in quarter $t$ versus cash flows and book profits from derivatives positions in quarter $t$ 1 , conditional on hedging activity. Hedge ratio volatility is estimated as the absolute value of the difference in the logs of the hedge ratio from the beginning to the end of the quarter. $C F$ is the total derivatives cash flow; $S C F$ is selective hedging cash flow; $B C F$ is the benchmark cash flow; DELTA_CFO and $V E G A \_C F O$ are the managerial compensation sensitivities for the CEO. The regressions include the Inverse Mills ratio estimated on the first stage of the Heckman procedure. $* * *, * *$, * indicate significance at the $1 \%, 5 \%$ and $10 \%$ levels, respectively. Robust tstatistics corrected for cluster effects are reported in parentheses.

\begin{tabular}{|c|c|c|c|c|c|c|c|c|}
\hline & \multicolumn{2}{|c|}{$\begin{array}{c}\text { Volatility of } \\
\text { one-year hedge ratio }\end{array}$} & \multicolumn{2}{|c|}{$\begin{array}{c}\text { Volatility of } \\
\text { aggregate 3-year ratio } \\
\text { scaled by production }\end{array}$} & \multicolumn{2}{|c|}{$\begin{array}{c}\text { Volatility of } \\
\text { aggregate 3-year ratio } \\
\text { scaled by reserves }\end{array}$} & \multicolumn{2}{|c|}{$\begin{array}{c}\text { Volatility of } \\
\text { aggregate 5-year ratio } \\
\text { scaled by reserves }\end{array}$} \\
\hline & (1) & (2) & (3) & (4) & (5) & (6) & (7) & (8) \\
\hline Intercept & $\begin{array}{r}-1.4314 \\
(-0.66)\end{array}$ & $\begin{array}{r}-1.4416 \\
(-0.65)\end{array}$ & $\begin{array}{r}-4.1473 \\
(-1.51)\end{array}$ & $\begin{array}{r}-4.1741 \\
(-1.46)\end{array}$ & $\begin{array}{r}-3.1787 \\
(-1.78)\end{array}$ & $\begin{array}{l}-3.1686 * \\
(-1.71)\end{array}$ & $\begin{array}{r}-1.6036 \\
(-1.22)\end{array}$ & $\begin{array}{r}-1.6082 \\
(-1.21)\end{array}$ \\
\hline $\mathrm{CF}$ & $\begin{array}{l}0.05655^{* *} \\
(2.48)\end{array}$ & & $\begin{array}{l}0.0499 \text { ** } \\
(2.59)\end{array}$ & & $\begin{array}{l}0.039 \\
(2.86)\end{array}$ & & $\begin{array}{c}0.0409 \\
(2.65)\end{array}$ & \\
\hline SCF & & $\begin{array}{r}0.0749 \\
(1.50)\end{array}$ & & $\begin{array}{c}0.0834 \\
(1.88)\end{array}$ & & $\begin{array}{l}0.06 \\
(2.09)\end{array}$ & & $\begin{array}{l}0.055^{* *} \\
(2.16)\end{array}$ \\
\hline BCF & & $\begin{array}{l}0.0543^{* *} \\
(2.52)\end{array}$ & & $\begin{array}{l}0.0465 \\
(2.46)\end{array}$ & & $\begin{array}{l}0.0366 \text { *** } \\
(2.75)\end{array}$ & & $\begin{array}{l}0.03888^{* *} \\
(2.55)\end{array}$ \\
\hline DELTA_CFO & $\begin{array}{r}0.2539 \\
(0.82)\end{array}$ & $\begin{array}{r}0.2132 \\
(0.74)\end{array}$ & $\begin{array}{r}0.5191 \\
(1.20)\end{array}$ & $\begin{array}{r}0.4235 \\
(1.02)\end{array}$ & $\begin{array}{r}0.3593 \\
(1.35)\end{array}$ & $\begin{array}{r}0.3118 \\
(1.22)\end{array}$ & $\begin{array}{r}0.2366 \\
(1.21)\end{array}$ & $\begin{array}{r}0.2194 \\
(1.16)\end{array}$ \\
\hline VEGA_CFO & $\begin{array}{r}-0.1079 \\
(-0.40)\end{array}$ & $\begin{array}{r}-0.0499 \\
(-0.19)\end{array}$ & $\begin{array}{r}-0.1494 \\
(-0.48)\end{array}$ & $\begin{array}{r}-0.0148 \\
(-0.05)\end{array}$ & $\begin{array}{r}-0.0575 \\
(-0.33)\end{array}$ & $\begin{array}{r}0.0109 \\
(0.07)\end{array}$ & $\begin{array}{r}-0.0678 \\
(-0.47)\end{array}$ & $\begin{array}{r}-0.0478 \\
(-0.34)\end{array}$ \\
\hline $\begin{array}{l}\text { Inverse Mills } \\
\text { Ratio }\end{array}$ & $\begin{array}{r}3.3311 \\
(1.08)\end{array}$ & $\begin{array}{r}3.2148 \\
(1.05)\end{array}$ & $\begin{array}{r}2.9886 \\
(1.22)\end{array}$ & $\begin{array}{r}2.6094 \\
(1.12)\end{array}$ & $\begin{array}{r}2.0427 \\
(1.18)\end{array}$ & $\begin{array}{r}1.785 \\
(1.07)\end{array}$ & $\begin{array}{r}0.7582 \\
(1.15)\end{array}$ & $\begin{array}{r}0.9108 \\
(1.16)\end{array}$ \\
\hline$\overline{\mathrm{R}^{2}}$ & 0.1164 & 0.1209 & 0.176 & 0.1986 & 0.2023 & 0.2212 & 0.1606 & 0.1736 \\
\hline F-statistic & 2.06 & 1.84 & 1.88 & 1.93 & 2.22 & 2.13 & 1.91 & 1.65 \\
\hline Observations & 68 & 68 & 52 & 52 & 60 & 60 & 72 & 72 \\
\hline Clusters & 22 & 22 & 17 & 17 & 20 & 20 & 23 & 23 \\
\hline
\end{tabular}




\section{Table 9}

\section{Testing for Asymmetric Volatility Response with Selection}

The table reports the results of the second stage of the two-step Heckman procedure. In the first stage, we estimate the likelihood of hedging activity in a given quarter. In the second stage, we estimate the following regression of the three-year aggregate hedge ratio volatility on past selective hedging cash flows from derivatives positions, while allowing for an asymmetric response. The volatility is estimated as the absolute value of the difference in the logs of the hedge ratio in the end and the beginning of the quarter. $S C F$ is the selective hedging cash flow in the previous quarter. $B C F$ is the benchmark cash flow. $I_{1}$ is a dummy variable that equals one if the selective hedging cash flow during the last quarter was positive, and equals zero otherwise; and $I_{2}$ is a dummy variable that equals one if the selective hedging cash flow was negative, and equals zero otherwise. The Inverse Mills ratio is obtained on the first stage of the Heckman procedure. The second-stage regressions includes: firm size measured as the logarithm of the market value of assets; market-to-book ratio of assets; ratio of book debt to book equity; quick ratio; dividend dummy variable equal to one if the firm paid quarterly dividend; credit rating dummy variable equal to one if a firm reports a credit rating; and Altman's Z-score. Seasonal dummies are included in each model and ***, **, * indicate significance at the $1 \%, 5 \%$ and $10 \%$ levels, respectively. Robust t-statistics corrected for cluster effects are reported in parentheses.

\begin{tabular}{|c|c|c|c|c|}
\hline & $\begin{array}{c}\text { Volatility of } \\
\text { one-year hedge ratio }\end{array}$ & $\begin{array}{c}\text { Volatility of } \\
\text { aggregate 3-year ratio } \\
\text { scaled by production } \\
\end{array}$ & $\begin{array}{c}\text { Volatility of } \\
\text { aggregate 3-year ratio } \\
\text { scaled by reserves } \\
\end{array}$ & $\begin{array}{c}\text { Volatility of } \\
\text { aggregate 5-year ratio } \\
\text { scaled by reserves } \\
\end{array}$ \\
\hline & (1) & (2) & (3) & (4) \\
\hline Intercept & $\begin{array}{l}4^{4.6787^{* * *}} \\
(3.04)\end{array}$ & $\begin{array}{l}3.56311^{* *} \\
(2.07)\end{array}$ & $\begin{array}{l}3.3262^{* * *} \\
(2.91)\end{array}$ & $\begin{array}{l}2.3019^{* *} \\
(2.01)\end{array}$ \\
\hline $\mathrm{SCF} \times \mathrm{I}_{1}$ & $\begin{array}{l}0.0369^{* * *} \\
(3.85)\end{array}$ & $\begin{array}{c}0.0280^{*} \\
(1.84)\end{array}$ & $\begin{array}{l}0.0292 \\
(5.09)\end{array}$ & $\begin{array}{l}0.0278^{* * *} \\
(4.87)\end{array}$ \\
\hline $\mathrm{SCF} \times \mathrm{I}_{2}$ & $\begin{array}{r}-0.0207 \\
(-1.19)\end{array}$ & $\begin{array}{r}0.0147 \\
(1.38)\end{array}$ & $\begin{array}{r}0.0039 \\
(0.43)\end{array}$ & $\begin{array}{r}0.0025 \\
(0.31)\end{array}$ \\
\hline BCF & $\begin{array}{r}0.0076 \\
(1.00)\end{array}$ & $\begin{array}{r}0.0097 \\
(1.57)\end{array}$ & $\begin{array}{r}0.0079 \\
(1.56)\end{array}$ & $\begin{array}{c}0.0057^{*} \\
(1.82)\end{array}$ \\
\hline $\begin{array}{l}\text { Inverse Mills } \\
\text { Ratio }\end{array}$ & $\begin{array}{c}-4.4532 \\
(-2.15)\end{array}$ & $\begin{array}{r}-3.57 \\
(-1.45)\end{array}$ & $\begin{array}{l}-3.5717^{* *} \\
(-2.19)\end{array}$ & $\begin{array}{r}-1.6059 \\
(-1.08)\end{array}$ \\
\hline Dummies & YES & YES & YES & YES \\
\hline Controls & YES & YES & YES & YES \\
\hline$\overline{\mathrm{R}^{2}}$ & 0.077 & 0.0505 & 0.0879 & 0.0781 \\
\hline F-statistic & 4.6 & 3.43 & 5.48 & 4.24 \\
\hline Observations & 588 & 445 & 528 & 610 \\
\hline Clusters & 53 & 41 & 51 & 53 \\
\hline
\end{tabular}




\section{SFB 649 Discussion Paper Series 2012}

For a complete list of Discussion Papers published by the SFB 649, please visit http://sfb649. wiwi.hu-berlin.de.

001 "HMM in dynamic HAC models" by Wolfgang Karl Härdle, Ostap Okhrin and Weining Wang, January 2012.

002 "Dynamic Activity Analysis Model Based Win-Win Development Forecasting Under the Environmental Regulation in China" by Shiyi Chen and Wolfgang Karl Härdle, January 2012.

003 "A Donsker Theorem for Lévy Measures" by Richard Nickl and Markus Reiß, January 2012.

004 "Computational Statistics (J ournal)" by Wolfgang Karl Härdle, Yuichi Mori and Jürgen Symanzik, January 2012.

005 "Implementing quotas in university admissions: An experimental analysis" by Sebastian Braun, Nadja Dwenger, Dorothea Kübler and Alexander Westkamp, January 2012.

006 "Quantile Regression in Risk Calibration" by Shih-Kang Chao, Wolfgang Karl Härdle and Weining Wang, January 2012.

007 "Total Work and Gender: Facts and Possible Explanations" by Michael Burda, Daniel S. Hamermesh and Philippe Weil, February 2012.

008 "Does Basel II Pillar 3 Risk Exposure Data help to Identify Risky Banks?" by Ralf Sabiwalsky, February 2012.

009 "Comparability Effects of Mandatory IFRS Adoption" by Stefano Cascino and J oachim Gassen, February 2012.

010 "Fair Value Reclassifications of Financial Assets during the Financial Crisis" by Jannis Bischof, Ulf Brüggemann and Holger Daske, February 2012.

011 "Intended and unintended consequences of mandatory IFRS adoption: A review of extant evidence and suggestions for future research" by Ulf Brüggemann, Jörg-Markus Hitz and Thorsten Sellhorn, February 2012.

012 "Confidence sets in nonparametric calibration of exponential Lévy models" by Jakob Söhl, February 2012.

013 "The Polarization of Employment in German Local Labor Markets" by Charlotte Senftleben and Hanna Wielandt, February 2012.

014 "On the Dark Side of the Market: Identifying and Analyzing Hidden Order Placements" by Nikolaus Hautsch and Ruihong Huang, February 2012.

015 "Existence and Uniqueness of Perturbation Solutions to DSGE Models" by Hong Lan and Alexander Meyer-Gohde, February 2012.

016 "Nonparametric adaptive estimation of linear functionals for low frequency observed Lévy processes" by J ohanna Kappus, February 2012.

017 "Option calibration of exponential Lévy models: Implementation and empirical results" by Jakob Söhl und Mathias Trabs, February 2012.

018 "Managerial Overconfidence and Corporate Risk Management" by Tim R. Adam, Chitru S. Fernando and Evgenia Golubeva, February 2012. 